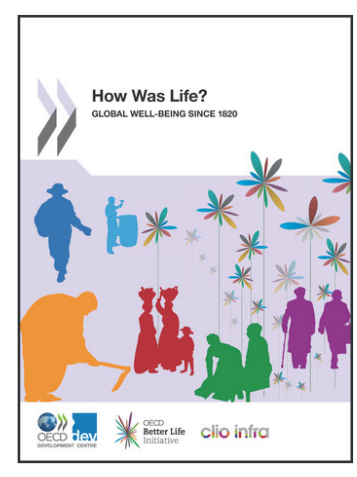

\section{From:}

How Was Life?

Global Well-being since 1820

Access the complete publication at:

http://dx.doi.org/10.1787/9789264214262-en

\title{
Education since 1820
}

Bas van Leeuwen, Jieli van Leeuwen-Li

Please cite this chapter as: 
This work is published on the responsibility of the Secretary-General of the OECD. The opinions expressed and arguments employed herein do not necessarily reflect the official views of the OECD member countries, or those of the IISH.

This document and any map included herein are without prejudice to the status of or sovereignty over any territory, to the delimitation of international frontiers and boundaries and to the name of any territory, city or area. 


\section{Chapter 5}

\section{Education since 1820}

by

Bas van Leeuwen and Jieli van Leeuwen-Li, Utrecht University*

Education provides many direct and indirect benefits to people's well-being. This chapter relies upon two indicators to describe educational inequalities around the globe since 1820: literacy rates and years of schooling. These indicators are based on merging two major datasets that rely mainly on population census data, and that have various strengths and limitations. The chapter shows that trends in education have a tight relationship with those in GDP per capita. In 1820, less than $20 \%$ of the world's population was literate, and this group was heavily concentrated in Western Europe and the Western Offshoots. Nowadays, levels of literacy are close to $100 \%$ almost everywhere, with Africa being the most significant exception (at 64\%). In the wake of the expansion of basic education, secondary and tertiary education also expanded in all parts of the world, first in the Western Offshoots, then in Western Europe. More recently this became a global phenomenon, resulting in a strong increase in the average years of education of the world population, from around 1 year in 1870, to 3 years after the Second World War, to more than 7 years in the new millennium.

* Acknowledgement: We thank Fabrice Murtin and Herman de Jong for comments on an earlier draft, and Lotte van der Vleuten for supplying us with some of the data on literacy. We would also like to thank the participants in the OECD workshop on historical well-being held at the OECD headquarters in Paris in December 2013; their contributions to the discussion helped to improve this paper. 


\section{Introduction}

Literacy and education is nowadays considered a prime right for all human beings. The right to literacy and an education has been declared a human right in Article 2 of the first protocol to the European Convention on Human Rights since 1952 and, since 1966, by Article 13 of the United Nations' International Covenant on Economic, Social and Cultural Rights. Indeed, it is hard to imagine our societies without some basic level of education, as this opens up opportunities for people and brings benefits in both the material and nonmaterial components of well-being (OECD, 2011a).

Having some basic level of literacy or education directly improves a person's wellbeing by providing more control over his or her life. After all, having some basic levels of reading and writing skills are necessary for everyday transactions in shops, commercial enterprise and household economics (e.g. Spence et al., 2009). In addition, being able to read and write allows enjoying activities that bring intrinsic pleasure to an individual, like reading or going to a museum of art (OECD, 2011b).

Literacy and education also affect well-being indirectly. This can be by enhancing economic development, as education may lead to more productive labour, or by using technology, which increases productivity (e.g. Romer, 1990). In addition, this may also have non-material effects such as increasing political stability (e.g. Alesina and Perotti, 1996), lowering crime rates (Sabates, 2008), improving health (OECD, 2010), or reducing inequality by increasing skills at the bottom of the income ladder (e.g. OECD, 2011a).

Yet, with some notable exceptions (e.g. Baier et al., 2006; Van Leeuwen and Foldvari, 2008a; Morrisson and Murtin, 2009; 2013; Foldvari et al., forthcoming), no estimates are available that provide a picture of the development of education and/or literacy over the past two centuries. In this chapter we will therefore try to remedy this issue by providing an admittedly tentative picture of educational development since the 1820 s.

\section{Description of the concepts used}

Our first indicator is literacy (i.e. the ability to read and write texts). It is important to stress though, that literacy in this sense acquired this meaning only in the late 19th century. Before then, the primary meaning of literacy had been "educated" or "learned" (Education for All, 2006, 148). The more limited interpretation that arose in the late 19th century mainly reflected the rapid increase in mass education, which consisted of little more than basic literacy and numeracy skills for the mass of the population. Around 1890 the ability to read and write had been acquired by around $20-40 \%$ of the population aged 15 years and older outside Europe and 60-70\% in Europe (UNESCO 1953, pp. 169-171). A mere 50 years later most developed countries had reached literacy levels of close to $100 \%$, while a significant rise had also taken place in the developing countries, re-instating the importance of the older definition of literacy as "education".

Literacy as a measure solely of the stock of knowledge in society was quickly made obsolete by 19th century economic and social developments. Technical change required 
a level of education that went beyond mere literacy in order to invent or operate new machines, and higher levels of education further increased personal security and the chance for a long and healthy life. By the 20th century, when in many countries literacy rates approached 100\%, this measure no longer provided much information about educational development, not to mention its inability to capture the increase in skills that can be acquired only at higher levels of education.

Therefore, many studies have proposed a version of educational attainment as a better measure, as it captures the number of people aged 15 or more who have followed either primary, secondary or higher levels of education (e.g. Barro and Lee 1993; 2010). This indicator is close, but not identical, to literacy, since some people who are literate may not have had an education while, vice versa, some people who had only a few years of schooling may have become illiterate over time. Although apparently uncontroversial, these levels of education and their educational contents may vary strongly between countries. In the 1970s UNESCO therefore designed the first International Standard Classification of Education (ISCED), which was revised in 1997 and 2011, which tries to incorporate existing national characteristics as much as possible. Here, primary education is defined as giving children a comprehensive schooling and laying a basis for possible further subjectoriented education. Primary education does not start before age 5 or after age 7 , and lasts no longer than about 6 years. Secondary education moves towards a more subject-oriented programme, educates for either the labour market or higher education, and lasts between 3 and 6 years. Finally, higher education is strongly subjected-oriented and basically covers all post-secondary education.

Even though educational attainment tells us that a person received some education, it does not tell us how long they did this. Educational attainment is therefore frequently converted into "average years of education", which is the number of years the average person aged 15 or over spent in formal education. While it can be argued that this variable captures education only to a limited extent, because it ignores the quality of education, it is still popular because it balances the existing quantitative evidence with a variable that captures the main stages in educational development. Therefore, in addition to literacy, this chapter uses average years of education as its second key indicator. Doing this has required the development of a dataset that covers 8 world regions and 146 countries, the sources for which will be discussed in the following section.

\section{Historical sources}

\section{Literacy}

The literacy data used were mainly taken from census data, since alternative sources, such as the number of people able to make a signature, may result in fundamentally different outcomes. The reason is that in most censuses literacy is defined in terms of the ability to read, write and understand a short, simple statement about everyday life, and this is not always consistent with the information derived from alternative sources such as signatures on marriage certificates.

The census data are derived from three main sources. For the period before 1950, we used the data from the UNESCO report on the Progress of Literacy in Various Countries Since 1900. This resulted in 173 observations for 30 countries. For the mid-20th century, we used the UNESCO report on Illiteracy at Mid-Century, which added another set of observations for 36 countries. Up to 1970 we used the UNESCO statistical yearbooks (various issues), followed 
by data from Gapminder ${ }^{1}$ from 1970 onwards. Finally, we included data for Tanzania from Egero and Henin (1967).

Unfortunately, these data run back only to the end of the 19th century, when this narrow concept of literacy first took root. Data on alternative measures, such as the number of people signing a marriage certificate, are available only for a very limited number of countries (mainly in Europe), and, in addition, do not conform completely to the definition given by UNESCO. Nevertheless, some data are available, such as from Mironov (1985) for European Russia, from Van Leeuwen (2007) for India, and from Pamuk and Van Zanden for several European countries (2007).

\section{Years of education}

As pointed out, once countries have come close to $100 \%$ literacy this indicator does not convey any further information, therefore many studies have reverted to average years of education in the population aged 15 and older. These studies are based on educational attainment by level of education, multiplied by the average time a student has spent at a certain level of education.

Many of these studies exist on a national level (e.g. Prados de la Escoura and Roses, 2010), yet a few scholars have created datasets on a wider scale, such as Barro and Lee $(1993 ; 2010)$ and Cohen and Soto (2007) for the entire world, and De la Fuente and Domenech (2000) for OECD countries. These datasets, however, supply estimates only at a few benchmark years from 1950 on. Three other datasets exist that have a wide coverage as well as a long temporal perspective. The first is by Baier et al. (2006), covering a set of countries at irregular intervals. A second, more comprehensive set of estimates is from Morrisson and Murtin (2009) for around 78 countries for 10-year intervals. A third set of estimates, from Van Leeuwen, Van Leeuwen-Li and Foldvari, has been published in a range of papers spread over the past years (e.g. Van Leeuwen and Foldvari, 2008a; Foldvari et al., forthcoming) and has been made available in a comprehensive format by Clio-Infra in 2012. The last two datasets, from Van Leeuwen et al. and Morrisson and Murtin, have been shown to be the ones with the widest coverage, the longest time span and the highest reliability (e.g. Foldvari et al., forthcoming). The methodology for the two is also roughly comparable, making it possible to combine the two sets of estimates into a single comprehensive dataset on educational development.

Without going into much detail on the exact computational strategies, the basic way most studies calculate years of education is to start with the available census data for the second half of the 20th century at decadal intervals. Three methods have been proposed to expand the number of observations (e.g. Wossman, 2003). First, there is the so-called perpetual inventory method. This method adds up all students over the past lifetime (about 60 years) and subtracts people who died. In this way, the number of people with certain levels of education is calculated. This method, however, has met with some severe criticism, since it does not correct for education-specific mortality (i.e. people with higher education generally live longer) and drop-outs (people who drop out of education before finishing their education). Hence, it will most likely underestimate the true levels of attainment. Second, there is the attainment census method. This method takes existing census data on educational attainment as its starting point and from there follows the perpetual inventory approach by adding new students and subtracting students in case of mortality. Consequently, even though the bias is less severe, it also results in lower-thanactual growth rates for educational attainment. Third, existing estimates in the census by 
age class are used to project education attainment, and hence years of education, backward and forward. This last method is used by Cohen and Soto and, more recently, in Barro and Lee (2010) and is judged to produce by far the most reliable estimates. For the pre-1950 period we rely on the perpetual inventory method, which is linked to the census data of the 1960s. Since we use annual observations, we can correct for drop-outs while assuming the percentage of repeaters is the same as in 1960. We did not correct for education-specific mortality, but this bias is likely to have been less in historical periods, meaning that the bias caused by this method is also likely to be smaller in the pre-1960 period.

The Van Leeuwen et al. and Morrisson-Murtin dataset used in this chapter relies for both datasets on a modified version of the Cohen and Soto (2007) data after 1960 and, before then, on a perpetual inventory method combined with back-projection. In certain cases, when no data existed for Cohen and Soto, we used either Barro and Lee (2010) as benchmarks, creating our own benchmark from existing census data, or a perpetual inventory method based on population and enrolment data mainly obtained from Mitchell (2007a, b, c), the UNESCO statistical yearbooks (various issues), the United States census bureau, Maddison (2007), the Colonial Blue Books for the British colonies (various issues), Lindert (2004) and the United States Department of Education (1993). These data were supplemented with historical data for the Netherlands from Albers (1997) and for England from DePleijt (2011).

Even though it is possible to create annual data by using a combination of backward and forward projections and the perpetual inventory method, this approach was not used here. This method, developed by Foldvari and Van Leeuwen (2009) and Foldvari, Van Leeuwen, and Van Leeuwen-Li (forthcoming), utilises the fact that backward extrapolation using the PIM method results in an overestimate while forward calculation results in an underestimate. When back- and forward-calculated over the same number of years, these biases cancel out. This allows us to arrive in the future at an annual dataset of years of education for the world.

\section{Data quality}

\section{Limitations of education and literacy as a measure of well-being}

The rise, and later decline, of the restricted concept of literacy can also be found in the data. The narrow concept of literacy, defined by UNESCO as the percentage of people age 15 and above "who can, with understanding, read and write a short, simple statement on their everyday life", became increasingly recorded in the data from the end of the 19th century onwards and started to decline in importance when literacy approached $100 \%$ at the end of the 20th century.

Table 5.1. Literacy by years of schooling completed in the United States, 1947 People aged 14 years and older

\begin{tabular}{lc}
\hline Years of education & Percentage literate \\
\hline none & 19.9 \\
1 year & 33.4 \\
2 years & 53.8 \\
3 years & 80.8 \\
4 years & 95.3 \\
\hline
\end{tabular}

Source: "Progress of literacy in various countries: a preliminary statistical study of available census data since 1900", UNESCO (Paris, 1953) (Table 152). 
At that time, people not only underwent more and more formal education, but the years they spend in this type of education also increased. With this development, the chance of permanent literacy increased as well. Table 5.1 shows that in 1947 in the United States, $19.9 \%$ of all persons without any formal education were literate. This increased from $33.4 \%$ after 1 year of education to $95.3 \%$ after 4 years of education. The interesting feature is that the more years of education people follow on average, the closer literacy and attainment will be.

But how about at the start of the 19th century when there was very little formal education? In that situation we might expect that the share of people without formal education who still have a certain level of literacy (recall that this level was $19.9 \%$ in the United States in 1947) is much lower, since very few people are around to teach them, and their parents will also have had limited or no literacy. Unfortunately, our attainment data does not stretch back to the start of the 19th century. Yet we can test this assumption by looking at those countries at the start of the 20th century with hardly any formal education. If our hypothesis is true, we would expect literacy to be below 19.9\%. For example, India in 1900 had an attainment of only $4.7 \%$ and a literacy of 6\%, while in Haiti in 1950 these figures had values of $15 \%$ and $10 \%$.

Hence, when formal education is very low, so are literacy rates. At higher levels of attainment, literacy rates can be expected to be lower than suggested by attainment, unless the few people that actually attained education all attain higher levels of education. ${ }^{2}$ Finally, at even higher levels of attainment, reached at the end of the 20th century, attainment and literacy rates once again start moving together.

With the rise of attainment the time spent in such education also started to increase, especially in the 20th century. Therefore, we include the more comprehensive indicator "average years of education" in this chapter. The choice of this indicator is a balance between the practical availability of data and the comprehensiveness of the indicator. After all, for the direct effect of education on well-being, for example to read a book or enjoy art, formal education, if provided in sufficient quantity, may very well be a good measure. After all, one does not need a high-quality university education to read a pamphlet, watch television or visit a museum. Neither are less easily quantifiable aspects of knowledge very important. Rarely are skills or on-the-job training important in this respect.

More problematic may be the indirect effects of education on well-being, both in terms of quantity and quality. Quantitatively, even though there is a large literature on job-searching where educational degrees are an important indicator for the employer (e.g. Autor and Dorn, 2013), factors such as innate ability, on-the-job training, learning by doing, and experience also play a role in finding jobs, and they affect personal income. In addition, besides adding to the quantity of knowledge, quality may play an important role in the relation between knowledge and per capita income (e.g. Romer, 1990). Educational development remains the most important component within the overall development of knowledge. Considering also its importance for direct effects on well-being, education is by far the variable that is most suited to being a proxy for well-being overall (e.g. Barro and Lee 1993; 2010).

In general, it can be assumed that any errors in the data presented here derive from three sources: first, the unreliability of the existing data; second, errors in converting to internationally comparable units; and third, the perpetual inventory method itself. Given the availability of census data and relatively reliable and homogenous enrolment 
rates, these problems are most likely less severe for the second half of the 20th century than for earlier periods. This obviously varies from country to country: before the 1970s the indicators are generally less reliable for African countries than for many European countries.

In order to give some indication of this, we subdivided the estimates into four classes (Table 5.2).Virtually all benchmark data after 1960 (i.e. 1960, 1970, 1980, 1990, 2000 and 2010) are derived indirectly from central statistical agencies and are therefore probably better classified as historical reconstructions. The remaining data are estimates.

Table 5.2. Quality of data on years of education by region and benchmark year, 1820-2008

\begin{tabular}{|c|c|c|c|c|c|c|c|c|}
\hline & $\begin{array}{l}\text { Western } \\
\text { Europe } \\
\text { (WE) }\end{array}$ & $\begin{array}{c}\text { Eastern } \\
\text { Europe } \\
\text { (EE) }\end{array}$ & $\begin{array}{l}\text { Western } \\
\text { Offshoots } \\
\text { (W0) }\end{array}$ & $\begin{array}{l}\text { Latin } \\
\text { America } \\
\text { and } \\
\text { Caribbean } \\
\text { (LA) }\end{array}$ & $\begin{array}{c}\text { Sub-Saharan } \\
\text { Africa } \\
\text { (SSA) }\end{array}$ & $\begin{array}{l}\text { Middle East } \\
\text { and } \\
\text { North Africa } \\
\text { (MENA) }\end{array}$ & $\begin{array}{c}\text { East Asia } \\
(E A)\end{array}$ & $\begin{array}{c}\text { South and } \\
\text { South-East } \\
\text { Asia } \\
\text { (SSEA) }\end{array}$ \\
\hline 1820 & 3 &.. &.. & .. &.. &.. &.. &.. \\
\hline 1870 & 3 & 4 & 3 & 4 & 4 & 4 & 4 & 4 \\
\hline 1913 & 3 & 3 & 3 & 3 & 3 & 3 & 3 & 3 \\
\hline 1950 & 2 & 2 & 2 & 2 & 3 & 3 & 3 & 3 \\
\hline 1973 & 2 & 2 & 2 & 2 & 2 & 2 & 2 & 2 \\
\hline 2008 & 2 & 2 & 2 & 2 & 2 & 2 & 2 & 2 \\
\hline
\end{tabular}

Note: 1. High quality; 2. Moderate quality; 3. Low quality; and 4. Estimates.

See the section on «Data Quality» in Chapter 1 for a description of the quality criteria.

Source: Clio-Infra, www.clio-infra.eu.

\section{Main highlights of education trends}

Using a combination of contemporaneous and historical data, we were able to estimate world literacy back to 1820 . In 1820 , roughly $12 \%$ of the world's people were literate, a number that doubled over the course of the 19th century, with another doubling between 1900 and 1990. Our data for educational attainment start only in 1870. However, utilising its relationship with literacy, a regression can be run to backcast attainment to 1820. Doing this indicates that about $17 \%$ of the world's population aged 15 and older had attained at least some basic education. We report this "best guess" figure as well as our other estimates of attainment until 2010 in Figure 5.1. As pointed out before, we do notice a divergence between educational attainment and literacy at the end of the 19th and start of the 20th century, which closed again at the end of the century.

This general picture of literacy and educational attainment hides large regional differences, however. Unsurprisingly, around 1870, the Western Offshoots and Western European countries had the highest attainment levels, at about $82 \%$ and $60 \%$ respectively, with Sub-Saharan Africa at a low 2\% (Table 5.3). This completely changed in the 21st century, when the share of the adult population with at least some basic education had increased to $79 \%$. By then, most regions had reached levels around $90 \%-100 \%$, except for South and Southeast Asia, the Middle East and North Africa, and Sub-Saharan Africa, which remained behind with attainment levels of around $60 \%$. 
Figure 5.1. World development of literacy and attainment of at least basic education, 1820-2010

Percentage of population aged over 15 literate or enrolled in formal education

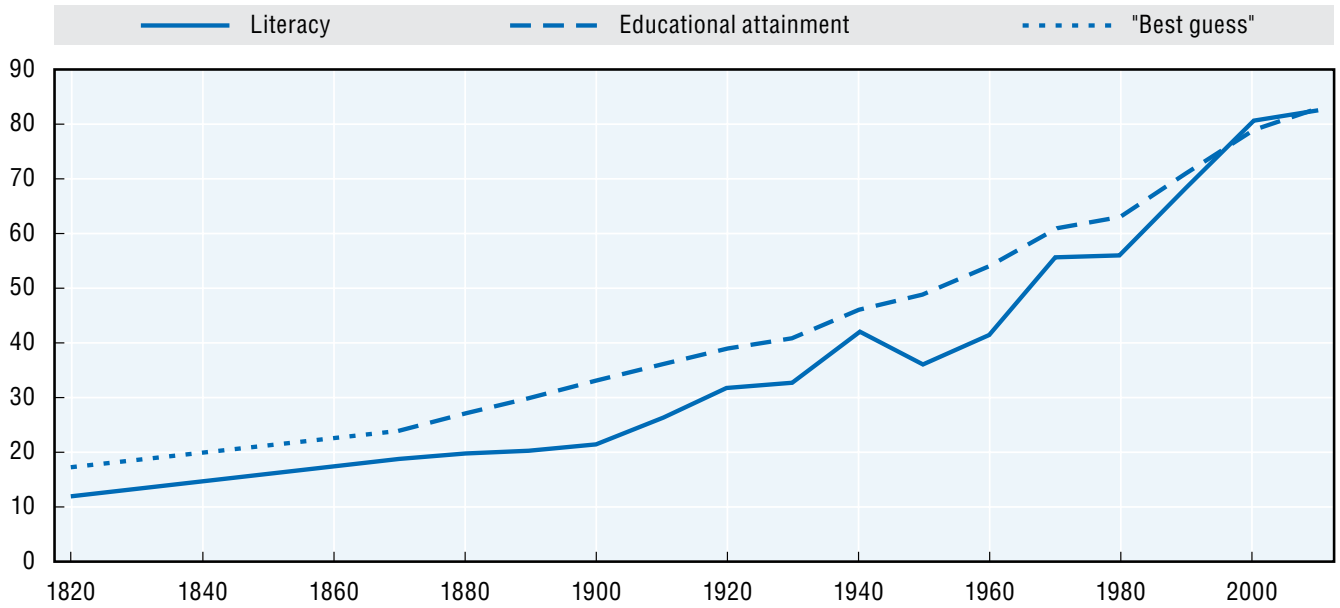

Note: For an assessment of data quality, see Table 5.2.

Source: Clio-Infra, www.clio-infra.eu.

Table 5.3. Population having attained at least basic education by region, $\mathbf{1 8 7 0 - 2 0 1 0}$ Percentage of population aged over 15 enrolled in formal education

\begin{tabular}{|c|c|c|c|c|c|c|c|c|c|}
\hline & $\begin{array}{l}\text { Western } \\
\text { Europe } \\
\text { (WE) }\end{array}$ & $\begin{array}{c}\text { Eastern } \\
\text { Europe } \\
\text { (EE) }\end{array}$ & $\begin{array}{l}\text { Western } \\
\text { Offshoots } \\
\text { (W0) }\end{array}$ & $\begin{array}{l}\text { Latin } \\
\text { America } \\
\text { and } \\
\text { Caribbean } \\
\text { (LA) }\end{array}$ & $\begin{array}{c}\text { East Asia } \\
(\mathrm{EA})\end{array}$ & $\begin{array}{c}\text { South and } \\
\text { South-East } \\
\text { Asia } \\
\text { (SSEA) }\end{array}$ & $\begin{array}{l}\text { Middle East } \\
\text { and } \\
\text { North Africa } \\
\text { (MENA) }\end{array}$ & $\begin{array}{c}\text { Sub-Saharan } \\
\text { Africa } \\
\text { (SSA) }\end{array}$ & World \\
\hline 1870 & 60.0 & 25.1 & 82.3 & 13.5 & 24.3 & 1.8 & 4.2 & 1.8 & 23.9 \\
\hline 1880 & 69.2 & 27.4 & 86.5 & 16.2 & 25.6 & 2.2 & 4.7 & 2.0 & 26.7 \\
\hline 1890 & 75.3 & 30.8 & 92.5 & 19.5 & 27.6 & 2.5 & 5.3 & 2.4 & 29.6 \\
\hline 1900 & 80.9 & 33.9 & 96.9 & 23.0 & 30.2 & 5.0 & 5.8 & 2.9 & 33.2 \\
\hline 1910 & 82.6 & 36.1 & 96.7 & 26.7 & 32.8 & 6.3 & 7.1 & 3.6 & 35.6 \\
\hline 1920 & 86.7 & 49.1 & 98.0 & 32.0 & 35.9 & 8.6 & 7.5 & 4.4 & 38.6 \\
\hline 1930 & 86.8 & 64.4 & 98.8 & 35.7 & 37.9 & 11.5 & 8.7 & 6.3 & 40.9 \\
\hline 1940 & 90.9 & 92.8 & 100.0 & 42.7 & 42.1 & 15.2 & 10.5 & 9.5 & 45.9 \\
\hline 1950 & 91.3 & 97.1 & 100.0 & 54.0 & 45.8 & 19.7 & 14.0 & 13.4 & 49.0 \\
\hline 1960 & 93.9 & 98.5 & 100.0 & 55.5 & 56.2 & 25.6 & 21.1 & 20.4 & 53.7 \\
\hline 1970 & 96.0 & 98.5 & 100.0 & 65.4 & 71.8 & 34.4 & 28.8 & 25.1 & 60.9 \\
\hline 1980 & 98.6 & 98.5 & 100.0 & 71.5 & 72.4 & 40.5 & 39.4 & 32.1 & 63.0 \\
\hline 1990 & 99.5 & 99.7 & 100.0 & 83.3 & 80.0 & 53.7 & 55.2 & 45.2 & 71.1 \\
\hline 2000 & 99.6 &.. & 100.0 & 90.0 & 87.1 & 65.9 & 66.3 & 58.4 & 78.5 \\
\hline 2010 & 99.8 & .. & 100.0 & 93.5 & 89.8 & 70.3 & 73.8 & 65.4 & 81.5 \\
\hline
\end{tabular}

Note: For an assessment of data quality, see Table 5.2.

Source: Clio-Infra, www.clio-infra.eu.

StatLink 司IST http://dx.doi.org/10.1787/888933095742

The reasons for this massive spread of formal education relate to the development of channels through which education affects well-being, i.e. the direct relation with wellbeing, as well as indirect material and immaterial benefits. The demand for education by the population increased because it supplied social standing and access to the market, while its supply increased because the government wanted to educate citizens who 
were able to participate in the political process (e.g. Glaeser et al., 2007). This increase in mass education then took on its own dynamic, in which the demand for and supply of education both increased, albeit in certain regions more than in others (e.g. Murtin and Viarengo, 2011).

These basic numbers (see Tables 5.4 and 5.5) show that education has spread throughout the world at an ever increasing rate throughout the 20th century, giving the great majority of the world population access to the written word. Gaps between regions as well as between the sexes have diminished. The direct effect on well-being was an enormous increase in people's potential to enjoy the written word. Indeed, as shown by Plopeanu et al. (2014), the number of printed book titles in the United Kingdom increased in the 19th century from about 1000 to more than 6000 a year, suggesting an increasing demand for books and literature. However, Africa remained significantly behind: in the 1950s in Europe the number of book titles per million inhabitants per year was 343 versus a mere 28 in Africa. There was also immense progress in terms of indirect effects on well-being. In many countries higher levels of education contributed to economic growth, because of the adoption or invention of new technologies that increased labour productivity (e.g. Van Leeuwen and Foldvari, 2008a), increased life expectancy (Castelló-Climent and Doménech, 2007), empowered women (Nussbaum, 2003) and reduced crime (Eicher et al., 2009).

Technological developments also create counter-forces to this trend. For example, an increasing amount of information is available via the internet. Even though the number of books in Africa increased, the continent lagged massively in access to this new medium

Table 5.4. Average years of education by region, $\mathbf{1 8 5 0 - 2 0 1 0}$ Years

\begin{tabular}{|c|c|c|c|c|c|c|c|c|c|}
\hline & $\begin{array}{l}\text { Western } \\
\text { Europe } \\
\text { (WE) }\end{array}$ & $\begin{array}{c}\text { Eastern } \\
\text { Europe } \\
\text { (EE) }\end{array}$ & $\begin{array}{c}\text { Western } \\
\text { Offshoots } \\
\text { (W0) }\end{array}$ & $\begin{array}{l}\text { Latin } \\
\text { America } \\
\text { and } \\
\text { Caribbean } \\
\text { (LA) }\end{array}$ & $\begin{array}{c}\text { East Asia } \\
\text { (EA) }\end{array}$ & $\begin{array}{c}\text { South and } \\
\text { South-East } \\
\text { Asia } \\
\text { (SSEA) }\end{array}$ & $\begin{array}{l}\text { Middle East } \\
\text { and } \\
\text { North Africa } \\
\text { (MENA) }\end{array}$ & $\begin{array}{c}\text { Sub-Saharan } \\
\text { Africa } \\
\text { (SSA) }\end{array}$ & World \\
\hline 1850 & .. & .. & .. & .. & 0.8 & .. & .. & .. & 0.9 \\
\hline 1860 & .. & .. & .. & .. & 0.8 & .. & .. & .. & 1.0 \\
\hline 1870 & 3.5 & 0.9 & 5.5 & 0.6 & 1.0 & 0.1 & 0.2 & 0.1 & 1.2 \\
\hline 1880 & 4.0 & 1.0 & 5.9 & 0.8 & 1.1 & 0.1 & 0.3 & 0.1 & 1.3 \\
\hline 1890 & 4.5 & 1.2 & 6.5 & 0.9 & 1.1 & 0.2 & 0.3 & 0.1 & 1.5 \\
\hline 1900 & 5.0 & 1.5 & 7.0 & 1.1 & 1.3 & 0.3 & 0.4 & 0.1 & 1.7 \\
\hline 1910 & 5.5 & 1.7 & 7.5 & 1.4 & 1.4 & 0.4 & 0.4 & 0.2 & 2.0 \\
\hline 1920 & 5.9 & 2.1 & 7.8 & 1.7 & 1.5 & 0.5 & 0.5 & 0.2 & 2.2 \\
\hline 1930 & 6.2 & 2.7 & 8.5 & 2.0 & 1.7 & 0.7 & 0.6 & 0.3 & 2.5 \\
\hline 1940 & 6.6 & 3.8 & 8.9 & 2.4 & 2.0 & 1.0 & 0.8 & 0.5 & 2.8 \\
\hline 1950 & 7.0 & 4.7 & 9.6 & 3.0 & 2.4 & 1.3 & 1.1 & 0.8 & 3.2 \\
\hline 1960 & 7.8 & 5.4 & 10.2 & 3.7 & 3.3 & 1.7 & 1.6 & 1.2 & 3.8 \\
\hline 1970 & 9.0 & 6.5 & 10.9 & 4.4 & 4.3 & 2.4 & 2.2 & 1.6 & 4.5 \\
\hline 1980 & 10.1 & 8.1 & 11.8 & 5.3 & 5.5 & 3.2 & 3.3 & 2.1 & 5.3 \\
\hline 1990 & 11.0 & 9.4 & 12.7 & 6.7 & 6.4 & 4.0 & 4.7 & 3.0 & 6.1 \\
\hline 2000 & 11.5 & 10.3 & 13.0 & 7.6 & 7.7 & 5.1 & 6.0 & 3.8 & 7.2 \\
\hline 2010 & 11.9 & 11.3 & 13.5 & 8.1 & 8.4 & 5.7 & 6.7 & 4.2 & 7.7 \\
\hline
\end{tabular}

Note: For an assessment of data quality, see Table 5.2. Source: Clio-Infra, www.clio-infra.eu. 
Table 5.5. Average years of education in selected countries, $\mathbf{1 8 5 0 - 2 0 0 0}$ Years

\begin{tabular}{|c|c|c|c|c|c|c|c|c|c|c|c|c|c|c|c|c|c|c|c|c|c|c|c|c|c|}
\hline & \multicolumn{7}{|c|}{$\begin{array}{l}\text { Western Europe } \\
\text { (WE) }\end{array}$} & \multicolumn{2}{|c|}{$\begin{array}{c}\text { Eastern Europe } \\
\text { (EE) }\end{array}$} & \multicolumn{3}{|c|}{$\begin{array}{l}\text { Western Offshoots } \\
\text { (WO) }\end{array}$} & \multicolumn{3}{|c|}{$\begin{array}{l}\text { Latin America and } \\
\text { Caribbean } \\
\text { (LA) }\end{array}$} & \multicolumn{2}{|c|}{$\begin{array}{l}\text { Middle East } \\
\text { and North } \\
\text { Africa (MENA) }\end{array}$} & \multicolumn{3}{|c|}{$\begin{array}{c}\text { Sub-Saharan Africa } \\
\text { (SSA) }\end{array}$} & \multicolumn{2}{|c|}{$\begin{array}{l}\text { East Asia } \\
\quad(\mathrm{EA})\end{array}$} & \multicolumn{3}{|c|}{$\begin{array}{c}\text { South and } \\
\text { South-East Asia } \\
\text { (SSEA) }\end{array}$} \\
\hline & GBR & NLD & FRA & DEU & ITA & ESP & SWE & POL & RUS & AUS & CAN & USA & MEX & BRA & ARG & EGY & TUR & KEN & NGA & ZAF & $\mathrm{CHN}$ & JPN & IND & IDN & THA \\
\hline 1820 & 1.8 & 2.0 & .. & .. & .. & .. & .. & .. & .. & .. & .. & .. & .. & .. & .. & .. & .. & .. & .. & .. & .. & .. & .. & .. & .. \\
\hline 1830 & 1.9 & 2.0 & .. & .. & .. & .. & .. & .. & .. & .. & .. & .. & .. & .. & .. & .. & .. & .. & .. & .. & .. & .. & .. & .. & .. \\
\hline 1840 & 2.2 & 2.5 & .. & .. & .. & .. & .. & .. & .. & .. & .. & .. & .. & .. & .. & .. & .. & .. & .. & .. & .. & .. & .. & .. & .. \\
\hline 1850 & 2.6 & 3.0 & .. & .. & .. & .. & .. & .. & .. & 1.1 & .. & .. & .. & .. & .. & .. & .. & .. & .. & .. & 0.8 & .. & .. & .. & .. \\
\hline 1860 & 3.1 & 4.0 & .. & .. & .. & .. & .. & .. & .. & 1.5 & .. & .. & .. & .. & .. & .. & .. & .. & .. & .. & 0.8 & .. & .. & .. & .. \\
\hline 1870 & 3.6 & 5.1 & 4.1 & 5.4 & 0.8 & 1.5 & 4.2 & .. & 0.9 & 3.1 & 5.7 & 5.6 & 0.6 & 0.5 & 1.5 & 0.2 & 0.3 & 0.2 & 0.0 & 1.1 & 1.0 & 1.0 & 0.1 & 0.0 & 0.2 \\
\hline 1880 & 4.4 & 5.2 & 4.9 & 5.7 & 1.3 & 2.0 & 4.6 & .. & 1.0 & 4.2 & 6.2 & 6.0 & 0.7 & 0.6 & 1.6 & 0.2 & 0.3 & 0.3 & 0.0 & 1.1 & 1.1 & 1.1 & 0.1 & 0.0 & 0.2 \\
\hline 1890 & 4.8 & 5.4 & 5.8 & 6.1 & 1.9 & 2.6 & 5.0 & .. & 1.1 & 5.3 & 6.7 & 6.6 & 0.9 & 0.6 & 1.8 & 0.2 & 0.4 & 0.4 & 0.0 & 1.1 & 1.1 & 1.5 & 0.2 & 0.0 & 0.3 \\
\hline 1900 & 5.3 & 5.6 & 6.3 & 6.5 & 2.4 & 3.1 & 5.5 & .. & 1.2 & 6.2 & 7.1 & 7.1 & 1.1 & 0.7 & 2.1 & 0.3 & 0.5 & 0.4 & 0.0 & 1.1 & 1.2 & 2.2 & 0.3 & 0.0 & 0.3 \\
\hline 1910 & 5.9 & 5.8 & 7.0 & 7.0 & 2.8 & 3.5 & 5.9 & .. & 1.3 & 7.1 & 7.6 & 7.5 & 1.3 & 0.9 & 2.5 & 0.4 & 0.5 & 0.5 & 0.0 & 1.1 & 1.2 & 2.9 & 0.4 & 0.1 & 0.4 \\
\hline 1920 & 6.3 & 6.1 & 7.5 & 7.5 & 3.4 & 3.7 & 6.2 & 2.4 & 1.9 & 7.7 & 8.0 & 7.8 & 1.4 & 1.0 & 3.1 & 0.4 & 0.6 & 0.6 & 0.0 & 1.4 & 1.3 & 3.9 & 0.5 & 0.1 & 0.4 \\
\hline 1930 & 6.7 & 6.4 & 7.7 & 7.7 & 3.9 & 3.8 & 6.5 & 2.5 & 2.5 & 8.4 & 8.5 & 8.5 & 1.5 & 1.3 & 3.7 & 0.7 & 0.6 & 0.7 & 0.0 & 1.9 & 1.3 & 5.0 & 0.7 & 0.2 & 0.5 \\
\hline 1940 & 7.2 & 6.8 & 8.0 & 8.2 & 4.4 & 4.6 & 6.8 & 3.0 & 3.9 & 8.9 & 8.8 & 8.9 & 1.9 & 1.6 & 4.5 & 1.0 & .. & 0.8 & 0.2 & 2.4 & 1.5 & 5.8 & 0.9 & 0.4 & 1.0 \\
\hline 1950 & 7.7 & 7.1 & 8.1 & 8.5 & 5.0 & 4.9 & 7.4 & 3.2 & 5.0 & 9.4 & 9.2 & 9.6 & 2.5 & 2.4 & 5.4 & 1.5 & 1.2 & 1.2 & 0.4 & 3.1 & 1.7 & 6.8 & 1.2 & 0.9 & 1.8 \\
\hline 1960 & 8.9 & 8.0 & 8.4 & 9.7 & 5.5 & 5.6 & 8.5 & 4.2 & 6.6 & 10.0 & 9.5 & 10.3 & 3.4 & 3.1 & 6.2 & 1.6 & 2.2 & 1.9 & 1.1 & 4.0 & 2.5 & 8.6 & 1.5 & 1.7 & 2.6 \\
\hline 1970 & 10.2 & 9.0 & 10.0 & 11.1 & 6.6 & 6.4 & 9.7 & 5.3 & 7.9 & 10.7 & 9.9 & 11.1 & 4.4 & 3.8 & 6.8 & 1.8 & 3.1 & 2.8 & 1.3 & 4.9 & 3.5 & 10.1 & 2.0 & 3.0 & 3.2 \\
\hline 1980 & 11.4 & 10.0 & 11.1 & 12.3 & 7.8 & 7.3 & 11.0 & 6.7 & 9.1 & 11.9 & 11.2 & 11.9 & 5.5 & 4.7 & 7.7 & 3.1 & 4.2 & 4.0 & 1.5 & 5.2 & 4.6 & 11.0 & 2.7 & 3.8 & 4.1 \\
\hline 1990 & 12.2 & 10.7 & 11.5 & 13.1 & 9.1 & 8.4 & 11.8 & 7.6 & 9.8 & 12.7 & 12.2 & 12.7 & 6.9 & 6.6 & 7.8 & 5.2 & 5.3 & 5.2 & 2.7 & 5.8 & 5.6 & 11.8 & 3.3 & 6.1 & 6.6 \\
\hline 2000 & 13.1 & 11.3 & 11.8 & 12.9 & 10.3 & 9.5 & 11.5 & 8.8 & 9.4 & 13.0 & 12.8 & 13.0 & 8.0 & 7.5 & 8.4 & 6.8 & 6.3 & 6.1 & 4.0 & 7.4 & 6.9 & 12.7 & 4.5 & 7.3 & 7.6 \\
\hline
\end{tabular}

Note: For an assessment of data quality, see Table 5.2.

Source: Clio-Infra, www.clio-infra.eu. 
for the written word: whereas in the West close to $90 \%$ of the population has access to the internet, in Africa the figure is closer to $10-20 \%$. Similarly, the relation between education and material well-being has changed over time. In the 19th century the Western countries were still at the top of technical innovation, with about five years of education, a level that the African countries reached only at the end of the 20th century. But in the late 20th century the technological frontier had shifted upwards. MacMahon (1998) points out that the importance of secondary and higher education has increased over time, while Petrakis and Stamatakis (2002) elaborate on this by showing that the more economically developed a country is, the more important secondary and higher education are for economic development. But even in the less developed countries it is likely that the importance of secondary and higher education increases over time (e.g. Liu and Stengos, 1999). For example, Krueger and Lindahl $(2001,1130)$ estimated for the OECD that the effect of years of education on per capita GDP had an inverted U-shape, with a peak at around 7.5 years of education. The developing economies are substantially below this peak, suggesting that currently the effect of education on per capita GDP is low, and perhaps even insignificant.

\section{Correlation with GDP per capita}

It is important to stress nevertheless that, even though education may, in certain instances, have a limited (or changing) effect on per capita GDP over time, this does not imply that there is a low correlation between education and per capita income (see Figure 5.2). Disregarding the period before 1870, since there are simply too few observations to arrive at sensible correlations, we arrive, from 1870 onwards, at a correlation between these two indicators that is persistently high.

The reason for this tight relationship is that not only is education important for increasing per capita income, but per capita income may also affect education when countries invest significantly in the development of an education system, as is the case

\section{Figure 5.2. Correlation between average years of education and GDP per capita, 1870-2010}

Pearson correlation coefficient and upper/lower bounds of $95 \%$ confidence interval

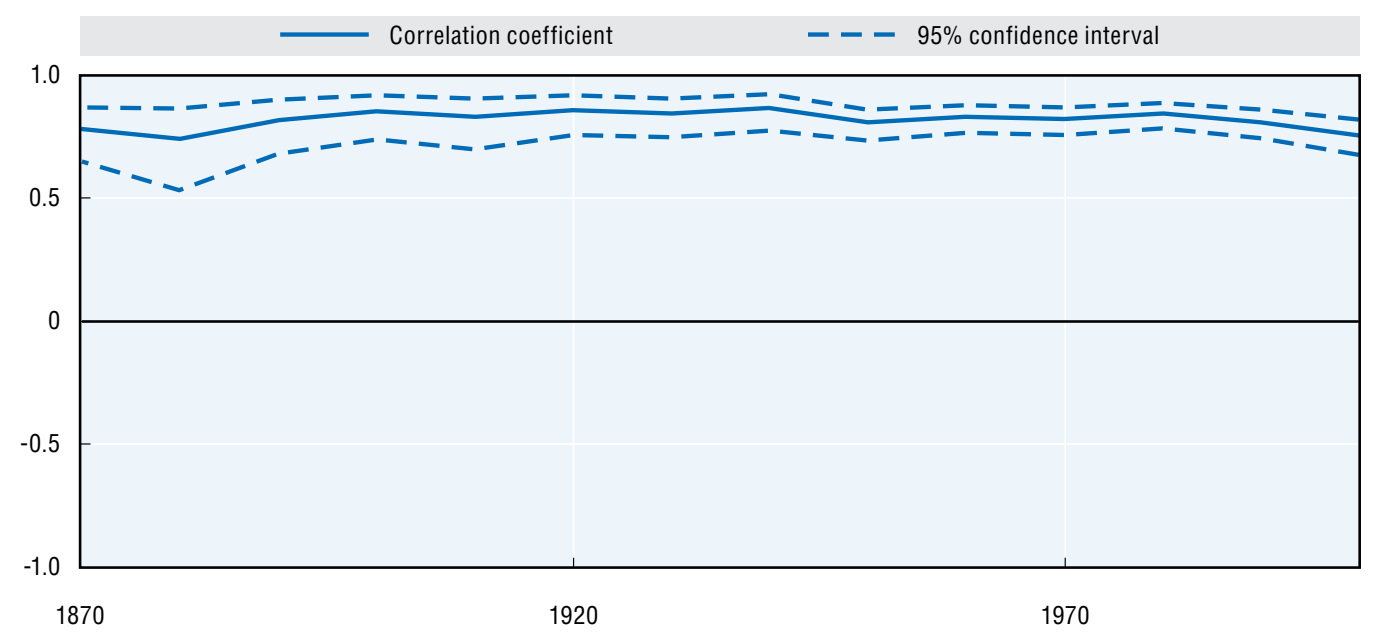

Note: For an assessment of data quality, see Table 5.2.

Source: Clio-Infra, www.clio-infra.eu. 
for many developing economies. In addition, the relationship between education and per capita income may also run through a plethora of other indicators, such as health and corruption.

\section{Priorities for future research}

Literacy and education are crucial variables determining well-being, since they not only directly influence a person's intrinsic agency, but also indirectly affect well-being in material (e.g. per capita income and wages) and immaterial terms (e.g. lower crime rates, higher life expectancy). In this chapter, we made an attempt to quantify literacy and education worldwide between the mid-19th century and 2010. In doing so we combined data from Van Leeuwen et al. and Morrison and Murtin into a single comprehensive database, which will be expanded further in the future.

Over time there has been convergence in levels of literacy and educational attainment, with only Africa lagging substantially behind. This convergence becomes less, or even turns into a divergence, once one corrects for the level of education: the Western countries and Western Offshoots still lead in terms of secondary and higher education.

These findings seem to suggest that, at least in terms education, there has been a massive improvement in well-being. However, two factors may still prove to be obstacles. First, over time the playing field is also changing: countries that try to catch up in terms of education meet increasingly higher demands in terms of their levels of education before the education they impart becomes as productive as in the developed countries. For example, where in the 19th century 2-4 years of education was enough to have a productive workforce, nowadays a country needs close to 6 or 7 years in order for education to begin to have a positive impact on per capita income. Second, there is still a significant difference across countries in terms of the quality of education, with the developed countries maintaining a significant lead (Van Leeuwen and Foldvari, 2008b). This will be work for the future. For the late 20th century several test scores are available which can be used to quantify educational quality, but for earlier periods we have to rely on alternative measures such as educational expenditure and teacher-pupil ratios.

\section{Notes}

1. See Gapminder.

2. This is easy to see from the numbers in Table 5.2. If we assume for simplicity's sake that everyone has only 2 years of education and that educational attainment is $40 \%$, this implies that we can calculate literacy to be $40 \% * 53.8+60 \% * 19.9=33.5 \%$, i.e. literacy is lower than attainment.

\section{References}

Albers, R. (1997), "Human capital and economic growth: operationalising growth theory, with special reference to the Netherlands in the 19th century", GGDC Research memorandum, GD-34.

Alesina, A. and R. Perotti (1996), "Income Distribution, Political Instability, and Investment", European Economic Review, Vol. 40/6, pp. 1203-1228.

Autor, D.H. and D. Dorn (2013), "The Growth of Low Skill Service Jobs and the Polarization of the U.S. Labor Market", American Economic Review, Vol. 103, pp. 1553-1597.

Baier, S., G. Dwyer, and R. Tamura (2006), "How Important are Capital and Total Factor Productivity for Economic Growth?" Economic Inquiry, Issue 44, pp. 23-49.

Barro, R.J. and J.-W. Lee (2010), "A New Data Set of Educational Attainment in the World, 1950-2010", NBER Working Paper, No. 15902. 
Barro, R.J. and J.-W. Lee (1993), "Institutional comparisons of educational attainment", Journal of Monetary Economics, Vol. 32/3, pp. 363-394.

Blue books of the British colonies (various issues).

Castelló-Climent, A. and R. Doménech (2008), "Human Capital Inequality, Life Expectancy and Economic Growth”, Economic Journal, Vol. 118/528, pp. 653-677.

Cohen, D. and M. Soto (2007), “Growth and human capital: good data, good results", Journal of Economic Growth, Vol. 12/1, pp. 51-76.

de Pleijt, S. (2011), "The Role of Human Capital in the Process of Economic Development: The Case of England, 1307-1900”, CGEH working paper no. 21.

Egero, B. and R.A. Henin (1967), "The population of Tanzania: an analysis of the 1967 population census”, CENSUS COLUME 6.

Eicher, T., G.C. arcía-Peñalosa and T. Van Ypersele, (2009), "Education, corruption, and the distribution of income", Journal of Economic Growth, Vol. 14 /3, pp 205-231.

Földvári, P. and B. Van Leeuwen (2009), "Average years of education in Hungary: annual estimates 1920-2006”, Eastern European Economics, Vol. 47/2, pp. 5-20.

Földvári, P., B. Van Leeuwen and J. Van Leeuwen-Li (forthcoming), "Educational and income inequality in Europe, 1870-2000", Cliometrica, Forthcoming.

Fuente, A. and R. Doménech (2000), "Human Capital in Growth Regressions: How Much Difference Does Data Quality Make?” OECD Economics Department Working Papers, No. 262 (2000), pp. 2-68.

Gapminder, Literacy rate, adult total (\% of people ages 15 and above), www.gapminder.org/data/, accessed 20 May 2013.

Glaeser, E.L., G.A.M. Ponzetto and A. Shleifer, (2007), “Why does democracy need education?” Journal of Economic Growth, Vol. 12/2, pp. 77-99.

Krueger, A.B. and M. Lindahl, (2001), "Education for Growth: Why and For Whom?” Journal of Economic Literature, Vol. 39/4, pp. 1101-1136.

Lindert, P.H. (2004), Growing Public: Social Spending and Economic Growth since the Eighteenth Century Vol. 2., Cambridge: Cambridge Univ. Press.

Liu, Z. and Th. Stengos (1999), "Non-Linearities in Cross-Country Growth Regressions: A Semiparametric Approach", Journal of Applied Econometrics, 14 (5), pp. 527-538.

MacMahon, W.W. (1998), "Education and Growth in East Asia”, Economics of Education Review, Vol. 17/2, pp. 59-172.

Maddison, A. (2007), "Contours of the World Economy, 1-2030 AD", Essays in Macro-Economic History, Oxford University Press, Oxford.

Mironov, B.N. (1985), “Gramotnost' v Rossii 1797-1917 godov”, Istoria SSSR, Vol. 4, pp. 137-153.

Mitchell, B.R. (2007), International Historical Statistics: Africa, Asia \& Oceania, 1750-2005, Palgrave Macmillan (5th edition), Basingstoke [etc.].

Mitchell, B.R. (2007), International Historical Statistics: The Americas, 1750-2005,: Palgrave Macmillan (5th edition).

Mitchell, B.R. (2007), International Historical Statistics: Europe, 1750-2005, Basingstroke [etc.]: Palgrave Macmillan (5th edition).

Morrisson, Ch. and F. Murtin (2009), “The Century of Education”, Journal of Human Capital, Vol. 3/1, pp. 1-42.

Morrisson, C. and F. Murtin (2013), “The Kuznets curve of human capital inequality: 1870-2010”, Journal of Economic Inequality, 11 (3), pp. 283-301.

Murtin, F. and Viarengo, M. (2011), "The expansion and convergence of compulsory schooling in Western Europe, 1950-2000”, Economica, 78 (311), pp. 501-522.

Nussbaum, M. (2003), “Women's Education: A Global Challenge”, Signs: Journal of Women in Culture and Society, 29 (2), pp. 325-355.

OECD (2011a), “Towards an OECD Skills Strategy”, Document Presented at the OECD Ministerial Council Meeting, Paris. 
OECD (2011b), How's Life?: Measuring Well-being, OECD Publishing, Paris, http://dx.doi.org/10.1787/ 9789264121164-en.

OECD (2010), Improving Health and Social Cohesion through Education, Educational Research and Innovation, OECD Publishing, http://dx.doi.org/10.1787/9789264086319-en.

Pamuk, S. and J.L. Van Zanden, (2007), “Standards of living, 1700-1870", third conference of "Unifying European Experience: Lessons of Pan-European Development", Marie Curie Training Network, London.

Pamuk, S. and J.L. van Zanden, (2010), "Standards of Living”, The Cambridge Economic History of Modern Europe, edited by Stephen Broadberry, and Kevin H. O'Rourke, Cambridge University Press.

Petrakis, P.E. and D. Stamatakis (2002), "Growth and Educational Levels: A Comparative Analysis", Economics of Education Review, Vol. 21/5, pp. 513-521.

Plopeanu, A., P. Foldvari, B. Van Leeuwen and J.L. Van Zanden (2014), "Where do ideas come from? Book production and patents in a global and temporal perspective", European Journal of Science and Theology, 10 (3), pp. 113-119.

Prados de la Escosura, L. and J. Rosés, (2010), "Human capital and economic growth in Spain, 1850-2000", Explorations in Economic History, Vol. 47/4, pp. 520-32.

Romer, P. (1990), “Endogenous Technological Change”, Journal of Political Economy, 98 (5), part 2, pp. 71-102.

Sabates, R. (2008), “Educational attainment and juvenile crime, Area-level analysis using three cohorts of young people", British Journal of Criminology, Vol. 48, pp. 395-409.

Spence, J., S.J. Aiston and M.M. Meikle (eds.) (2009), Women, education and agency, 1600-2000, Routledge, New York.

UNESCO (United Nations Educational, Scientific and Cultural Organization) (2006), Literacy for Life, Education for All, Global Monitoring Report, UNESCO Publishing, Paris.

UNESCO, Statistical Yearbook 1963-1999, UNESCO 1964-1999, Paris.

UNESCO (1957), World Illiteracy at Mid-Century, Paris: UNESCO, Paris.

UNESCO (1953), Progress of literacy in various countries: a preliminary statistical study of available census data since 1900, UNESCO, Paris.

United States Department of Commerce, United States Census Bureau, International database, downloaded from: www.census.gov/population/international/data/idb/informationGateway.php.

United States Department of Education (1993), 120 years of American education: a statistical portrait, USA: National Center for Education Statistics, http://nces.ed.gov/pubs93/93442.pdf.

van Leeuwen, B. and P. Földvári (2008a), "Human Capital and Economic Growth in Asia 1890-2000: a time-series analysis", Asian Economic Journal, Vol. 22/3, pp. 225-240.

van Leeuwen, B. (2007), Human capital and economic growth in India, Indonesia and Japan: A quantitative analysis: 1870-2000, PhD thesis Utrecht University.

van, Leeuwen, B. and P. Földvári, (2008b), "How much human capital does Eastern Europe have? Measurement methods and results", Post-Communist Economies, Vol. 20/2, pp. 189-201.

Wößmann, L. (2003), “Specifying Human Capital”, Journal of Economic Surveys, Vol. 17/3, pp. 239-270. 